\title{
Das Bild des Holländers in der deutschen Literatur
}

von Professor

Dr. Hermann Meyer

Amsterdam 


\section{ISBN 978-3-476-99687-9 ISBN 978-3-476-99686-2 (eBook) \\ DOI 10.1007/978-3-476-99686-2}

\section{Sonderdruck mit freundlicher Genehmigung der}

J. B. Metzlersche Verlagsbuchhandlung C. E. Poeschel Verlag, Stuttgart, aus H. Meyer „Zarte Empirie“.

Herausgeber: Fraternité Mondiale - Deutsche Fraternitas e. V., Düsseldorf Druck: Niederrh. Druckerei GmbH · Dinslaken - Hans-Böckler-Str. 23 - Ruf 5481 